AperTO - Archivio Istituzionale Open Access dell'Università di Torino

Tiny, glassy, and rapidly trapped: The nano-sized planktic diatoms in Messinian (late Miocene) gypsum.

This is a pre print version of the following article:

Original Citation:

Availability:

This version is available http://hdl.handle.net/2318/1798415

since 2023-03-17T16:22:44Z

Published version:

DOI:10.1130/G49342.1

Terms of use:

Open Access

Anyone can freely access the full text of works made available as "Open Access". Works made available under a Creative Commons license can be used according to the terms and conditions of said license. Use of all other works requires consent of the right holder (author or publisher) if not exempted from copyright protection by the applicable law. 


\title{
Tiny, glassy, and rapidly trapped: The nano-sized planktic diatoms in Messinian (late Miocene) gypsum
}

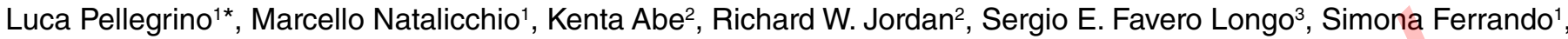 \\ Giorgio Carnevale ${ }^{1}$ and Francesco Dela Pierre ${ }^{1}$ \\ 1'Dipartimento di Scienze della Terra, Università degli Studi di Torino, 10125 Turin, Italy \\ ${ }^{2}$ Faculty of Science, Yamagata University, 990-8560 Yamagata, Japan \\ ${ }^{3}$ Dipartimento di Scienze della Vita e Biologia dei Sistemi, Università degli Studi di Torino, 10125 Turin, Italy
}

\begin{abstract}
Primary gypsum represents an excellent paleobiological archive due to its early and fast growth, favoring the preservation of delicate biomineralized structures. The Mediterranean region is renowned for evaporite deposits that formed during the Messinian salinity crisis (MSC), an event that supposedly annihilated most of the marine biota. However, the Messinian evaporites have been scarcely studied for their fossil content. Abundant nano-sized planktic diatoms and associated organic matter are observed for the first time in bottom-grown gypsum crystals that formed during the early stage of the MSC in different marginal basins of the western Mediterranean. This discovery increases our knowledge of the Messinian biota and reveals that nano-sized planktic diatoms played a prominent role in carbon and silicon export during gypsum deposition. The co-occurrence of these diatoms with larger diatoms, possibly associated with a deep chlorophyll maximum, suggests that Messinian gypsum formed in stratified and relatively deep basins (far below the photic zone), typified by marine conditions in the upper water column. The nano-sized planktic diatoms may have taken advantage of the hydrological reconfigurations experienced by the Mediterranean since the onset of the MSC. This study confirms that primary gypsum represents a promising archive of information for elucidating the marine biotic response to an ancient environmental crisis.
\end{abstract}

\section{INTRODUCTION}

Due to its fast and early growth, allowing for the rapid entombment of organic material, primary gypsum is an excellent archive of past life (Schopf et al., 2012). The paleobiological contents of gypsum can help in assessing paleoenvironmental conditions of ancient salt giants, whose reconstruction is hampered by the absence of modern analogues (Warren, 2010). In addition, gypsum represents a promising target for exploring the possibility of life on Mars (Benison and Karmanocky, 2014). Thick gypsum deposits formed in the Mediterranean at ca. 6 Ma during the Messinian salinity crisis (MSC; Fig. 1A), when this basin was turned into the youngest salt giant of Earth history (Roveri et al., 2014), with the supposed annihilation of most marine biota (Cita, 1976). The

*E-mail: lu.pellegrino@unito.it environmental conditions that governed Messinian gypsum deposition (salinity of the parent brines, depth of deposition) are still being debated (Natalicchio et al., 2014), and the study of the gypsum's fossiliferous content through unconventional in situ analyses and extraction techniques able to preserve delicate biogenic remains is pivotal for their reconstruction.

Apart from filamentous microfossils recently assigned to sulfide-oxidizing bacteria (Dela Pierre et al., 2015), Messinian gypsum contains well-preserved diatoms (Schopf et al., 2012; Carnevale et al., 2019) that have been, until now, poorly studied. Due to their sensitivity to environmental change, diatoms can help to decipher the physical and chemical conditions that occurred in the water column and on the seafloor during gypsum deposition, and their potential impact on the marine trophic chains and related biogeochemical cycles (Smol and Stoermer, 2010). We present an integrated petrographic, micropaleontological, Raman spectroscopic, and histochemical study of Messinian gypsum crystals from the Primary Lower Gypsum unit, reporting for the first time the occurrence of nano-sized planktic diatoms in these deposits. The results of our study can help to unravel the depositional environment of Messinian gypsum and may suggest that tiny, siliceous primary producers played a prominent role in carbon and silicon export at the beginning of the most recent environmental crisis experienced by the Mediterranean Sea.

\section{MATERIALS AND METHODS}

The Primary Lower Gypsum unit was deposited in Mediterranean peripheral basins during the first stage of the MSC (5.97-5.60 Ma; Roveri et al., 2014). It overlies pre-MSC open-marine sediments, including diatomites (Pellegrino et al., 2018), and displays a precession-driven lithological cyclicity marked by the alternation of shales and primary gypsum beds (Lugli et al., 2010). Shales were deposited during more humid climate at precession minima (insolation maxima), whereas gypsum reflects more arid climate at precession maxima (insolation minima). We studied 21 crystals taken from the lower two gypsum beds of the Primary Lower Gypsum unit from the Perales (southern Spain) and Banengo and Monticino (northern Italy) sections (Fig. 1A; see the Supplemental Material ${ }^{1}$ ). These beds were deposited during the course of two precessional cycles at the beginning of the MSC (from 5.97 to $5.95 \mathrm{Ma}$ ). They range in thickness from a few meters to $\sim 20 \mathrm{~m}$ and are composed of decimeter-long, twinned selenite crystals that formed on the bottom of a basin permanently covered by saturated brines (Lugli et al., 2010). These beds were selected for the large size of the

${ }^{1}$ Supplemental Material: Sampled sites, methodology, and sample list. Please visit https://doi.org/10.1130/XXXXX to access the supplemental material, and contact editing@geosociety.org with any questions.

CITATION: Pellegrino, L., et al., 2021, Tiny, glassy, and rapidly trapped: The nano-sized planktic diatoms in Messinian (late Miocene) gypsum: Geology, v. 49, p. XXX-XXX, https://doi.org/10.1130/G49342.1 

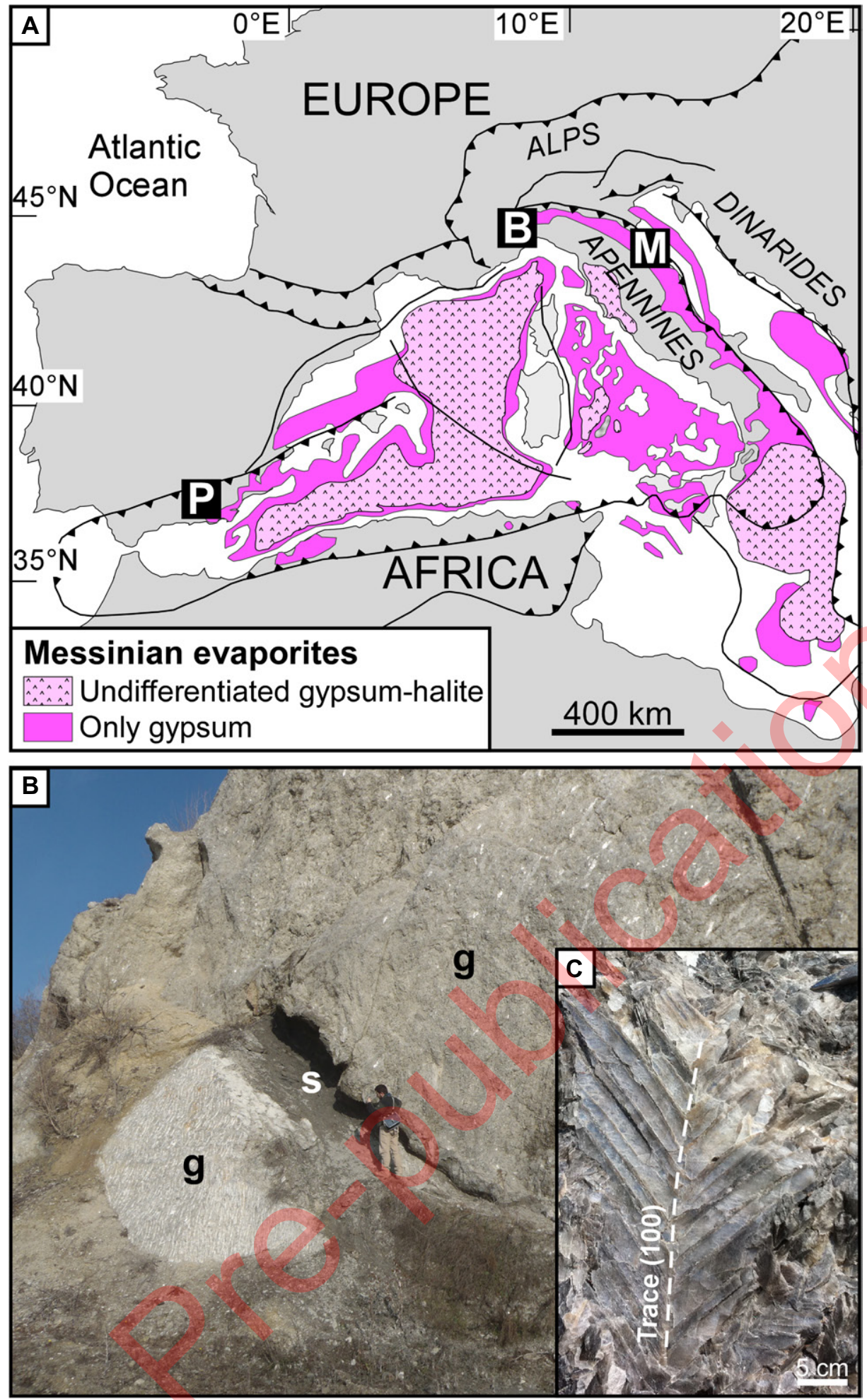

Figure 1. (A) Distribution of Messinian evaporites in the western Mediterranean Sea and location of studied sites (P-Perales, Spain; B-Banengo, Italy; M-Monticino, Italy). Modified from Roveri et al., 2014. (B) First and second Primary Lower Gypsum cycles (g-gypsum; s-shale), Banengo section. (C) Twinned selenite crystal from the first Primary Lower Gypsum bed of the Banengo section. Dashed line represents twinning plane.

crystals (Figs. 1B and 1C) and the abundance of entrapped biogenic particles.

We obtained 68 samples by splitting the crystals along the cleavage planes. Each sample was studied with transmitted- and reflected-light
(SEM-EDS); we stained one representative sample with periodic acid-Schiff (PAS) in order to evaluate the presence of preserved organic matter. Selected samples were dissolved in ultrapure water and the residues analyzed by SEM-EDS and micro-Raman spectroscopy (see the Supplemental Material).

\section{NANO-SIZED PLANKTIC DIATOMS IN MESSINIAN GYPSUM}

Abundant centric diatoms, on average $<10 \mu \mathrm{m}$, were found in the studied samples.

The nano-sized planktic diatoms (NPDs) were observed in both the re-entrant angle of the selenite twins (Figs. 2A-2C) and along the vertical growth bands (Figs. 2D-2F). They occur as dense aggregates composed of tens of entangled valves (Fig. 2G) or as smaller clumps (Fig. $2 \mathrm{H})$. The valves are roundish in valve view to slightly rectangular in girdle view (Figs. 2B, $2 \mathrm{C}, 2 \mathrm{~F}-2 \mathrm{H}$ ). According to their size, morphology, and ornamentation, the NPDs belong to the genus Thalassiosira (and mostly to the Thalassiosira oceanica complex; Figs. 2I-2L). Most of the valves are fluorescent when exposed to UV light, suggesting the presence of organic matter (Figs. 3A and 3B), further confirmed by micro-Raman spectroscopy (Fig. 3C) and the positive PAS staining (Fig. 3D). The latter points to the occurrence of carbohydrates or glycoconjugates. SEM observations of dissolved samples showed the presence of $\sim 0.1-\mu \mathrm{m}$-wide filaments in the inner portion of the valves or around them (Fig. 3E). These features possibly represent organic threads and/or residual extracellular polymeric substances (EPS), which are produced by the Thalassiosiraceae for chain formation or to enhance cell aggregation (Brunner et al., 2009; Kamalanathan et al., 2019). Raman analysis demonstrated that the valves are composed of opal (Fig. 3C). Beside NPDs, the planktic diatom assemblage comprises Chaetoceros vegetative cells and setae (Fig. 4A), remains of Rhizosolenia spp. (Figs. 4B and 4C), and larger Thalassiosiraceae. The benthic-epiphytic diatom assemblage comprises sparse specimens of Lampriscus sp. (Fig. 4D), Naviculaceae, and ribbon-like chains of Rhabdonema cf. adriaticum (Fig. 4E). Subordinated aggregates of long and tapered Bacillariaceae (Nitzschia spp.) also occur (Fig. 4F). Finally, basket-like structures resembling tintinnid loricae were observed (Fig. 4G). The background mass of the crystals is dominated by filaments (Fig. $4 \mathrm{H}$ ) and clayrich aggregates interpreted as marine snow floccules (Dela Pierre et al., 2015).

\section{NANO-SIZED PLANKTIC DIATOMS AS KEY PLAYERS IN CARBON AND SILICON EXPORT DURING GYPSUM DEPOSITION?}

The occurrence of abundant NPDs in coeval gypsum beds located thousands of kilometers 

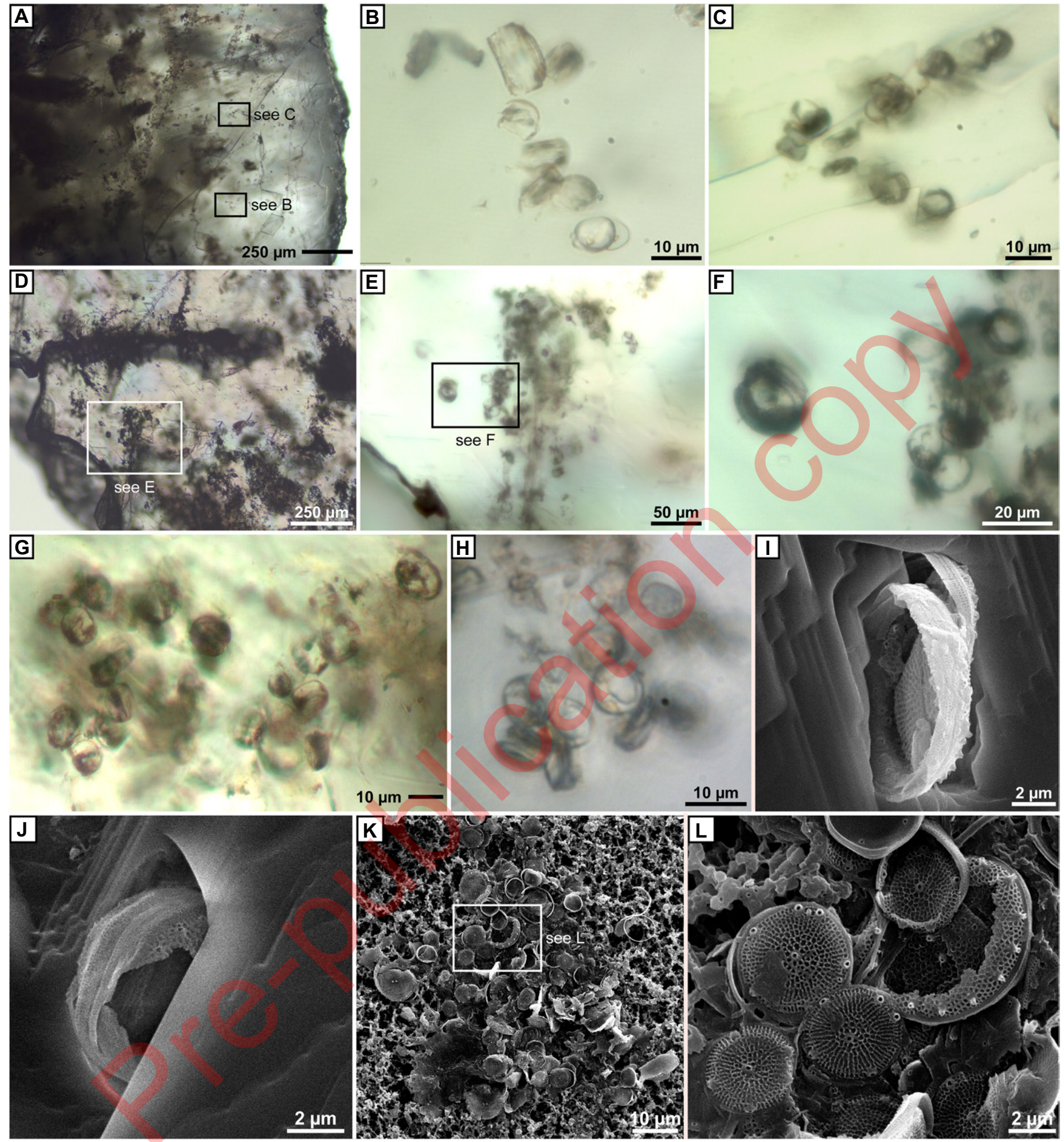

Figure 2. Transmitted light $(\mathrm{A}-\mathrm{H})$ and scanning electron microscopy (I-L) photomicrographs of nano-sized planktic diatoms from Perales (Spain) and Banengo (Italy) sections. (A-F) Aggregates in re-entrant angle (A-C) and along the vertical growth band (D-F) of a crystal. (G-H) Other representative nano-sized planktic diatom aggregates; note the densely entangled valves. (I,J) Single specimens of tiny Thalassiosira cf. oceanica (partially dissolved crystal). $(\mathrm{K}, \mathrm{L})$ Large aggregate of excellently preserved specimens (completely dissolved crystal).

apart highlights a Mediterranean-wide primary productivity event that involved small silicifiers at the beginning of the MSC. NPDs represent an overlooked component of the phytoplankton in modern oceans, where they play an underes- timated role in both carbon and silicon export (Leblanc et al., 2018). The tiny size of these diatoms seemingly precludes their rapid sinking (Legendre and Le Fèvre, 1995), limiting their contribution to the $\mathrm{C}$ and $\mathrm{Si}$ transfer to the seafloor. However, the aggregation of NPDs following massive blooms represents an effective mechanism for fast sinking (as fast as $80 \mathrm{~m}$ $\mathrm{d}^{-1}$ in the modern Mediterranean Sea; Leblanc et al., 2018). In the studied samples, diatom cell 

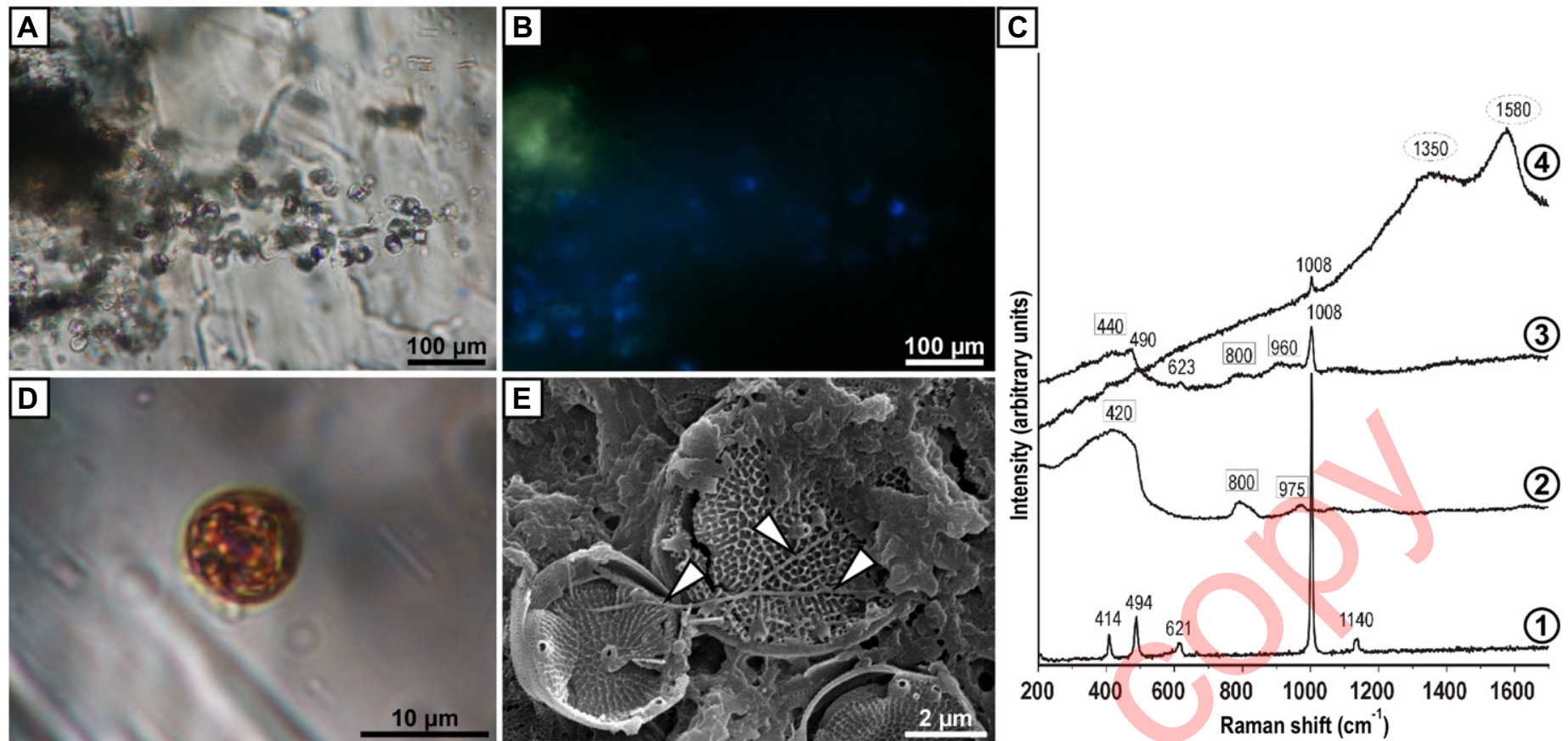

Figure 3. (A,B) Aggregate observed in transmitted (A) and ultraviolet (B) light microscopy. Note in B the high fluorescence of valves. (C) Micro-Raman spectra of (1) hosting gypsum (representative peak is unconfined); (2) opal-A from an isolated diatom valve used as a standard (representative band numbers within rectangles); (3) opal-A from nano-sized planktic diatoms extracted from the studied gypsum; and (4) poorly organized carbonaceous material (kerogen; band numbers within circles). (D) Periodic acid-Schiff (PAS)-positive (red stained) nanosized planktic diatoms. (E) Thin filaments (white triangles) in nano-sized planktic diatom aggregate (completely dissolved crystals).

aggregation is confirmed by the occurrence of clustered valves, while the contribution to carbon and silicon export at the beginning of the MSC is testified by the excellent preservation of organic matter and opal (Figs. 2 and 3).

Aggregation may have been mediated by grazing (through the egestion of fecal pellets) or self-induced (through the production of chitin threads and EPS). Although zooplankton grazing, perhaps by heterotrophic dinoflagellates (Buck and Newton, 1995) or copepods (Turner, 1978), is unable to completely crush the valves of tiny diatoms, digestion would have reduced their organic content, which is in contrast with the unusual preservation of organic matter and chitin threads in the studied gypsum (Fig. 3). Therefore, diatom sinking was most likely selfinduced. Interestingly, under controlled conditions, the chitin threads are rapidly degraded (Leblanc et al., 2018); so, once the aggregates reached the seafloor, the cells must have been rapidly entombed in the gypsum.

The studied gypsum is typified by interwoven filaments (Fig. $4 \mathrm{H}$ ) representing benthic microbial assemblages dominated by chemotrophic sulfide-oxidizing bacteria (Dela Pierre et al., 2015). Today, such assemblages are found in various settings, including those characterized by high productivity in the upper water column and bottom oxygen depletion. The high rate of sulfate reduction and consequent sulfide production are able to sustain sulfide-oxidizing prokaryotes on the seafloor (Bailey et al., 2009). In this light, the potential role of NPDs as carbon exporters may account for an unexplored source of organic matter exploitable by benthic bacteria involved in the sulfur biogeochemical cycle during gypsum deposition.

\section{PALEOENVIRONMENTAL IMPLICATIONS}

Messinian gypsum has been interpreted as the product of hypersaline environments (Rouchy and Monty, 2000; Rouchy and Caruso, 2006) by comparison with modern marine gypsum forming in evaporitic lagoons, sabkhas, and salterns (e.g., Oren et al., 2009). However, geochemical investigations of Messinian gypsum fluid inclusions showed that the parent brines had a salinity lower than that of normal seawater, questioning the formation of gypsum from evaporated seawater and the establishment of hypersaline depositional conditions (e.g., Natalicchio et al., 2014; Evans et al., 2015).

In our samples, the homogeneous distribution and excellent preservation of the aggregates exclude that NPDs were transported. Interestingly, centric diatoms like the Thalassiosiraceae preferentially thrive in marine to brackish waters (e.g., Hasle, 1983; Hoppenrath et al., 2007) and do not tolerate hypersaline conditions, even when salinity is well below the gypsum precipitation threshold (Noël, 1982; Madkour and Gaballah, 2012). These diatoms may contribute to the formation of a deep chlorophyll maximum (DCM) in the subsurface waters of modern oceans (Gould and Wiesenburg, 1990; Leblanc et al., 2018). In the studied crystals, the association of NPDs with typical components of the modern Mediterranean DCM like Chaetoceros spp. and Rhizosolenia spp. (Siokou-Frangou et al., 2010) agrees with the occurrence of a DCM during gypsum deposition, calling into question the establishment of hypersaline conditions in the water column. Only diatom species belonging to the genera Navicula and Nitzschia tolerate salinity ranges compatible with gypsum precipitation (Clavero et al., 2000). However, the halotolerant species belonging to these genera show a marked euryhalinity and therefore do not necessarily indicate hypersalinity.

The depth of marginal basins during Messinian gypsum deposition is another debated issue. The proposed depths range from very shallow (upper photic zone; Rouchy and Monty, 2000 ) to $\leq 200 \mathrm{~m}$ (within the photic zone; Roveri et al., 2014) to $>200 \mathrm{~m}$ (below the photic zone; Raad et al., 2020). The benthic-epiphytic diatoms preserved in the studied crystals cannot be used to constrain deposition in the photic zone. Their scattered occurrence and the fact they do not form mat-like aggregates, as their modern counterparts do, suggest resuspension and subsequent transport into the basin, likely by currents (Martínez-López et al., 2004). On the other hand, no precise paleobathymetric constraints are provided by NPDs. However, these diatoms have been reported in both shallow 

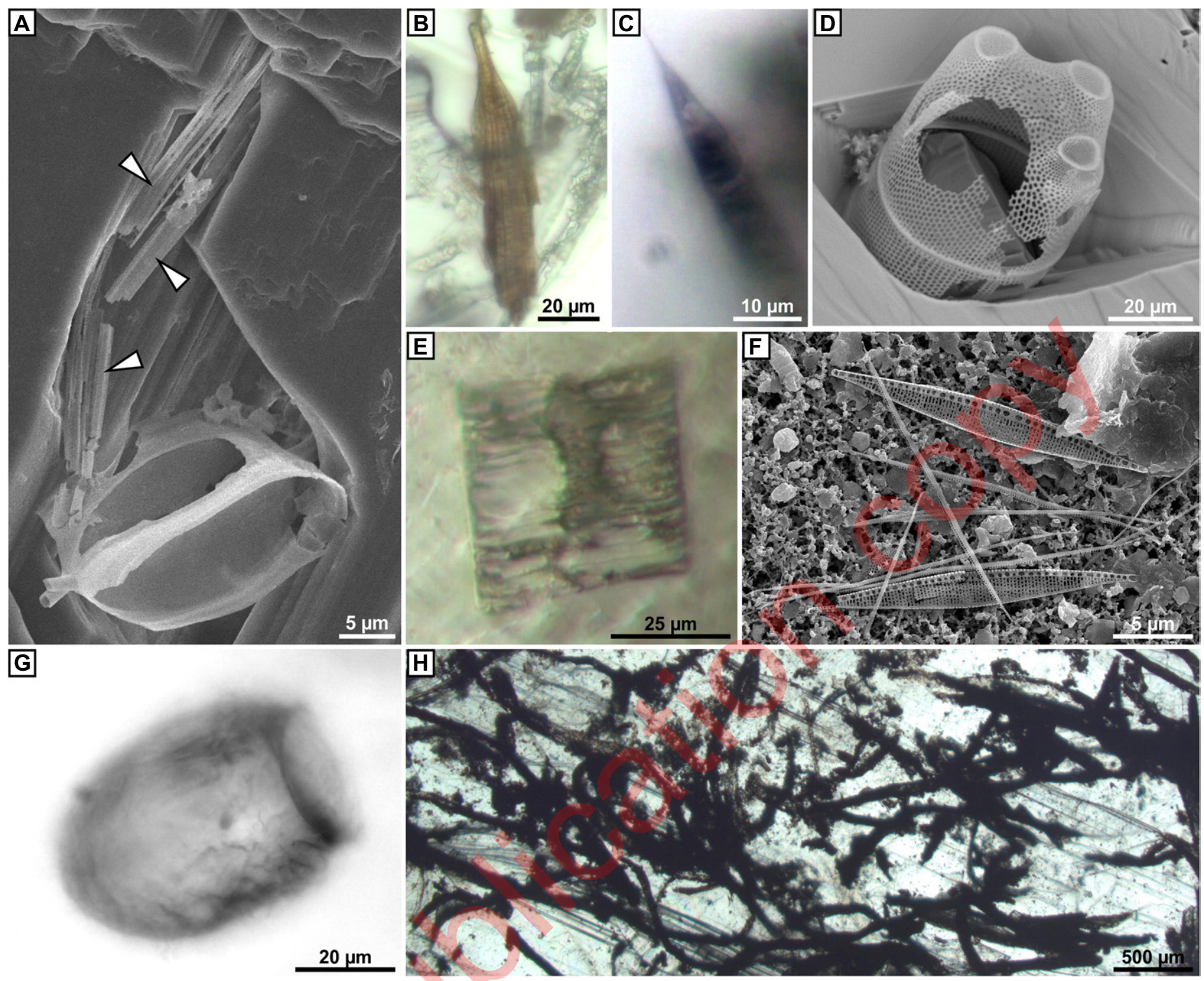

Figure 4. Scanning electron microscopy (A,D,F) and transmitted light (B,C,E,G,H) photomicrographs of representative components of studied crystals. (A-C) Large planktic diatoms: (A) Chaetoceros sp. vegetative valve and setae (white triangles; partially dissolved crystal); (B-C) Rhizosolenia spp. (D,E) Reworked benthic diatoms: (D) Lampriscus sp. (partially dissolved crystal); (E) Rhabdonema cf. adriaticum. (F) Nitzschia sp. (completely dissolved crystal). (G) Tintinnid lorica. (H) Interwoven filaments.

(i.e., a few meters; Hoppenrath et al., 2007) and deep (i.e., thousands of meters; Hasle, 1983) basins, suggesting that gypsum did not necessarily precipitate in very shallow basins but may have formed at greater water depths, far below the photic zone. The diatom assemblage of the studied gypsum samples differs from that of the pre-MSC (Pellegrino et al., 2018) diatomaceous deposits of the Mediterranean area. The latter are dominated by Thalassionema nitzschioides, which is found in biogenic laminae reflecting a relatively well-mixed water column where nutrients previously trapped at depth were reinjected into surface waters (Pellegrino et al., 2020). This diatom species is underrepresented in gypsum. Such compositional difference cannot be explained with selective dissolution of the valves, but most likely indicates a promi- nent paleohydrological change at the onset of the MSC. Such change could reflect the progressive isolation of the Mediterranean marginal basins from the oceanic domain and their increased sensitivity to freshwater inflows enhancing water-column stratification (Natalicchio et al., 2019). Considering their present-day ecology (Leblanc et al., 2018), NPDs may have been favored by the intensification of water-column stratification, thriving in surface and subsurface marine waters (together with other members of the DCM). In contrast, diatoms adapted to mixed conditions like T. nitzschioides (Schlüter et al., 2012) were likely disfavored.

\section{CONCLUSIONS}

The excellent preservation of the valves of NPDs and associated organic matter confirms the outstanding potential of gypsum as an archive of past life. These diatoms could have played a significant role in carbon and silicon export at the beginning of the MSC, possibly fueling benthic bacteria involved in the sulfur biogeochemical cycle. The massive occurrence of these diatoms suggests that gypsum does not necessarily reflect very shallow and hypersaline depositional conditions. Together with other components of the phytoplankton (e.g., larger diatoms) and zooplankton (e.g., tintinnids), NPDs highlight the complex trophic webs that persisted after the onset of the MSC in the water column, in contrast with the hypothesized almost-complete annihilation of the Mediterranean eukaryotic biota during the crisis. Future research on the detailed paleobiological content of the entirety of the Messinian gypsum 
deposits may reveal the still-unknown mechanisms responsible for their formation from lowsalinity parent brines and help to reconstruct the paleoenvironmental conditions of the youngest salt giant on our planet.

\section{ACKNOWLEDGMENTS}

This study was funded by University of Torino grants (DELF_RILO_19_01) to Dela Pierre. We thank S. Marabini for field assistance in the Monticino quarry. Comments and suggestions by the editor Gerald Dickens and three anonymous reviewers greatly improved the quality of the manuscript.

\section{REFERENCES CITED}

Bailey, J.V., Orphan, V.J., Joye, S.B., and Corsetti, F.A., 2009, Chemotrophic microbial mats and their potential for preservation in the rock record: Astrobiology, v. 9, p. 843-849, https://doi .org/10.1089/ast.2008.0314.

Benison, K.C., and Karmanocky, F.J., 2014, Could microorganisms be preserved in Mars gypsum? Insights from terrestrial examples: Geology, v. 42, p. 615-618, https://doi.org/10.1130/G35542.1.

Brunner, E., Richthammer, P., Ehrlich, H., Paasch, S., Simon, P., Ueberlein, S., and van Pée, K.-H., 2009, Chitin-based organic networks: An integral part of cell wall biosilica in the diatom Thalassiosira pseudonana: Angewandte Chemie, v. 48, p. 9724-9727, https://doi.org/10.1002/ anie. 200905028 .

Buck, K.R., and Newton, J., 1995, Fecal pellet flux in Dabob Bay during a diatom bloom: Contribution of microzooplankton: Limnology and Oceanography, v. 40, p. 306-315, https://doi.org/10.4319/ lo.1995.40.2.0306.

Carnevale, G., Gennari, R., Lozar, F., Natalicchio, M., Pellegrino, L., and Dela Pierre, F., 2019, Living in a deep desiccated Mediterranean Sea: An overview of the Italian fossil record of the Messinian salinity crisis: Bollettino della Società Paleontologica Italiana, v. 58, p. 109-140, https://doi .org/10.4435/BSPI.2019.04.

Cita, M.B., 1976, Biodynamic effects of the Messinian salinity crisis on the evolution of planktonic foraminifera in the Mediterranean: Palaeogeography, Palaeoclimatology, Palaeoecology, v. 20, p. 23-42, https://doi.org/10.1016/00310182(76)90023-7.

Clavero, E., Hernández-Mariné, M., Grimalt, J.O., and Garcia-Pichel, F., 2000, Salinity tolerance of diatoms from thalassic hypersaline environments: Journal of Phycology, v. 36, p. 1021-1034, https:// doi.org/10.1046/j.1529-8817.2000.99177.x.

Dela Pierre, F., Natalicchio, M., Ferrando, S., Giustetto, R., Birgel, D., Carnevale, G., Gier, S., Lozar, F., Marabello, D., and Peckmann, J., 2015, Are the large filamentous microfossils preserved in Messinian gypsum colorless sulfide-oxidizing bacteria?: Geology, v. 43, p. 855-858, https:// doi.org/10.1130/G37018.1.

Evans, P.N., Turchyn, A.V., Gázquez, F., Bontognali, T.R.R., Chapman, H.J., and Hodell, D.A., 2015, Coupled measurements of $\delta^{18} \mathrm{O}$ and $\delta \mathrm{D}$ of hydration water and salinity of fluid inclusions in gypsum from the Messinian Yesares Member, Sorbas Basin (SE Spain): Earth and Planetary Science Letters, v. 430, p. 499-510, https://doi .org/10.1016/j.eps1.2015.07.071.
Gould, R.W., Jr., and Wiesenburg, D.A., 1990, Single-species dominance in a subsurface phytoplankton concentration at a Mediterranean Sea front: Limnology and Oceanography, v. 35, p. 211-220, https://doi.org/10.4319/ lo.1990.35.1.0211.

Hasle, G.R., 1983, The marine, planktonic diatoms Thalassiosira oceanica sp. nov. and T. partheneia: Journal of Phycology, v. 19, p. 220-229, https:// doi.org/10.1111/j.0022-3646.1983.00220.x.

Hoppenrath, M., Beszteri, B., Drebes, G., Halliger, H., Van Beusekom, J.E.E., Janisch, S., and Wiltshire, K.H., 2007, Thalassiosira species (Bacillariophyceae, Thalassiosirales) in the North Sea at Helgoland (German Bight) and Sylt (North Frisian Wadden Sea)_A first approach to assessing diversity: European Journal of Phycology, v. 42, p. 271-288, https://doi .org/10.1080/09670260701352288.

Kamalanathan, M., et al., 2019, Role of polysaccharides in diatom Thalassiosira pseudonana and its associated bacteria in hydrocarbon presence: Plant Physiology, v. 180, p. 1898-1911, https:// doi.org/10.1104/pp.19.00301.

Leblanc, K., et al., 2018, Nanoplanktonic diatoms are globally overlooked but play a role in spring blooms and carbon export: Nature Communications, v. 9, 953, https://doi.org/10.1038/s41467018-03376-9.

Legendre, L., and Le Fèvre, J., 1995, Microbial food webs and the export of biogenic carbon in oceans: Aquatic Microbial Ecology, v. 9, p. 69-77, https:// doi.org/10.3354/ame009069.

Lugli, S., Manzi, V., Roveri, M., and Schreiber, B.C., 2010, The Primary Lower Gypsum in the Mediterranean: A new facies interpretation for the first stage of the Messinian salinity crisis: Palaeogeography, Palaeoclimatology, Palaeoecology, v. 297, p. 83-99, https://doi.org/10.1016/ j.palaeo.2010.07.017.

Madkour, F.F., and Gaballah, M.M., 2012, Phytoplankton assemblage of a solar saltern in Port Fouad, Egypt: Oceanologia, v. 54, p. 687-700, https://doi.org/10.5697/oc.54-4.687.

Martínez-López, A., Siqueiros-Beltrones, D., and Silverberg, N., 2004, Transport of benthic diatoms across the continental shelf off southern Baja California Peninsula: Ciencias Marinas, v. 30, p. 503513, https://doi.org/10.7773/cm.v30i4.347.

Natalicchio, M., Dela Pierre, F., Lugli, S., Lowenstein, T.K., Feiner, S.J., Ferrando, S., Manzi, V., Roveri, M., and Clari, P., 2014, Did Late Miocene (Messinian) gypsum precipitate from evaporated marine brines? Insights from the Piedmont Basin (Italy): Geology, v. 42, p. 179-182, https://doi .org/10.1130/G34986.1.

Natalicchio, M., et al., 2019, Paleoenvironmental change in a precession-paced succession across the onset of the Messinian salinity crisis: Insight from element geochemistry and molecular fossils: Palaeogeography, Palaeoclimatology, Palaeoecology, v. 518, p. 45-61, https://doi.org/10.1016/ j.palaeo.2019.01.009.

Noël, D., 1982, Les Diatomées des saumures des marais salants de Salin-de-Giraud (Sud de la France): Géologie Méditerranéenne, v. 9, p. 413-446, https://doi.org/10.3406/geolm.1982.1218.

Oren, A., Sørensen, K.B., Canfield, D.E., Teske, A.P., Ionescu, D., Lipski, A., and Altendorf, K., 2009, Microbial communities and processes within a hypersaline gypsum crust in a saltern evaporation pond (Eilat, Israel): Hydrobiologia, v. 626, p. 1526, https://doi.org/10.1007/s10750-009-9734-8.

Pellegrino, L., Dela Pierre, F., Natalicchio, M., and Carnevale, G., 2018, The Messinian diatomite deposition in the Mediterranean and its relationships to the global silica cycle: Earth-Science Reviews, v. 178, p. 154-176, https://doi.org/10.1016/j.earscirev.2018.01.018.

Pellegrino, L., Dela Pierre, F., Jordan, R.W., Abe, K., Mikami, Y., Natalicchio, M., Gennari, R., Lozar, F., and Carnevale, G., 2020, The upper Miocene diatomaceous sediments of the northernmost Mediterranean region: A lamina-scale investigation of an overlooked palaeoceanographic archive: Sedimentology, v. 67, p. 3389-3421, https://doi.org/10.1111/sed.12748.

Raad, F., Lofi, J., Maillard, A., Tzevahirtzian, A., and Caruso, A., 2020, The Messinian Salinity Crisis deposits in the Balearic Promontory: An undeformed analog of the MSC Sicilian basins?: Marine and Petroleum Geology, v. 124, 10477, https://doi.org/10.1016/j.marpetgeo.2020.104777.

Rouchy, J.M., and Caruso, A., 2006, The Messinian salinity crisis in the Mediterranean basin: A reassessment of the data and an integrated scenario: Sedimentary Geology, v. 188-189, p. 35-67, https://doi.org/10.1016/j.sedgeo.2006.02.005.

Rouchy, J.M., and Monty, C., 2000, Gypsum microbial sediments: Neogene and modern examples, in Riding, R.E., and Awramik, S.M., eds., Microbial Sediments: Berlin, Heidelberg, Springer, p. 209-216, https://doi.org/10.1007/978-3-66204036-2_23.

Roveri, M., et al., 2014, The Messinian Salinity Crisis: Past and future of a great challenge for marine sciences: Marine Geology, v. 352, p. 25-58, https://doi.org/10.1016/j.margeo.2014.02.002.

Schopf, J.W., Farmer, J.D., Foster, I.S., Kudryavtsev, A.B., Gallardo, V.A., and Espinoza, C., 2012, Gypsum-permineralized microfossils and their relevance to the search for life on Mars: Astrobiology, v. 12, p. 619-633, https://doi.org/10.1089/ ast.2012.0827.

Schlüter, M.H., Kraberg, A., and Wiltshire, K.H., 2012, Long-term changes in the seasonality of selected diatoms related to grazers and environmental conditions: Journal of Sea Research, v. 67, p. 91-97, https://doi.org/10.1016/j.seares.2011.11.001.

Siokou-Frangou, I., Christaki, U., Mazzocchi, M.G., Montresor, M., Ribera d'Alcalá, M., Vaqué, D., and Zingone, A., 2010, Plankton in the open Mediterranean Sea: A review: Biogeosciences, v. 7, p. 15431586, https://doi.org/10.5194/bg-7-1543-2010.

Smol, J.P., and Stoermer, E.F., eds., 2010, The Diatoms: Applications for the Environmental and Earth Sciences (second edition): New York, Cambridge University Press, 667 p., https://doi .org/10.1017/CBO9780511763175.

Turner, J.T., 1978, Scanning electron microscope investigations of feeding habits and mouthpart structures of three species of copepods of the family Pontellidae: Bulletin of Marine Science, v. 28, p. 487-500.

Warren, J.K., 2010, Evaporites through time: Tectonic, climatic and eustatic controls in marine and nonmarine deposits: Earth-Science Reviews, v. 98, p. 217-268, https://doi.org/10.1016/j.earscirev.2009.11.004.

Printed in USA 